\title{
The Effect of Freeze Dried Lactobacillus acidophilus Culture Concentration a Microbiological and Organoleptic Characteristics of Synbiotic Biscuits Made from Sorghum Flour and Soybean Flour
}

\author{
Een Sukarminah ${ }^{*}$, , Okta Paulia ${ }^{2}$, Debby M. Sumanti', Endah Wulandari1, \\ Elazmanawati Lembong1, Efri Mardawati ${ }^{3}$
1Department of Food-Industrial Technology, Faculty of Agro-industrial Technology Universitas Padjadjaran, Jatinangor, Bandung, Indonesia.
2Alumnae of Food- Technology, Faculty of Agro-industrial Technology Universitas Padjadjaran, Jatinangor, Bandung, Indonesia.
32Department of Agro-Industrial Technology, Faculty of Agro-industrial Technology Universitas Padjadjaran, Jatinangor, Bandung, Indonesia.

Email: een.sukarminah@unpad.ac.id*

\begin{abstract}
Sorghum flour and soybean flour can be processed as the main raw material in the manufacture of functional food product, namely synbiotic biscuits with addition of freeze dried Lactobacillus acidophilus culture. The purpose of study was to determine the concentration of freeze dried $L$. acidophilus culture on synbiotic biscuits made from sorghum flour and soybean flour with the best microbiological and organoleptic characteristics. The research method used was randomized block design with 4 treatments and 3 replications. The treatments were the freeze dried L. acidophilus concentration $8 \%, 10 \%, 12 \%$, and $14 \%$. The results of study showed that the addition of freeze dried culture of L. acidophilus to the synbiotic biscuits made from sorghum flour and soybean flour gave a significant different effect on total L. acidophilus probiotic bacteria, aroma and yield, but did not give a significant effect on the color, taste and texture preferences. Synbiotic biscuits made from sorghum flour and soybean flour with the addition of freeze dried $L$. acidophilus concentration of $14 \%(w / w)$ were selected as the synbiotic biscuit with the best characteristic with total bacterial content of probiotics 10,67 $\mathrm{Log} \mathrm{CFU}^{-1}$, were perceived a bit like to like by the panelist and the obtained yield was 92,14\%.
\end{abstract}

Keywords: Freeze dried L. acidophillus culture, sorghum flour, soybean flour, synbiotic biscuit.

\section{INTRODUCTION}

Society awareness about the importance of health triggers the number of functional food products in the market. According to [5], functional food is food that has been naturally or artificially processed into processed products or products, containing one or more functional components based on scientific studies have certain physiological functions, proven not harmful and beneficial to health. According to [12] quoted by [9], a substance can be classified as functional food if it fulfills one or both of the following criteria: (1) containing compounds (nutrients or nonnutrients) that affect one or several functions in the body positively; (2) provides psychological and physiological effects beyond the usual nutritional effects. Functional foods that are currently being developed are food products containing probiotics and prebiotics or a combination of both in a product known as synbiotic food.

Synbiotic is a combination of probiotics and prebiotics that can increase health benefits for body [7]. Probiotics are microbes that provide health benefits to the host through its effects in the intestinal system [12]. Prebiotics are undigested foods that act to stimulate the growth and or activity of one or more specific bacteria in the colon, which 
can improve host health. Many foods with oligosaccharides (including dietary fiber) are claimed to have prebiotic activity, although not all carbohydrates are prebiotic. Groups of oligosaccharides that have prebiotic activity are raffinose, fructo-oligosaccharides, galacto-oligosaccharides and transgalactosiloligosaccharides [12].

A good combination of probiotics and prebiotics can increase the number of good bacteria (probiotics) that can survive in the digestive system by fermenting the substrate. Cooperation between prebiotics and probiotics can be applied to the manufacture of functional food, one of which is a synbiotic biscuit. Biscuit is one food product that has been widely known by various circles of society and has a long shelf life. Biscuits are commonly consumed as a snack and can be stored because their light, strong and not easily damaged. Properties biscuits contain energy of $485 \mathrm{kcal}$ per 100 grams of edible parts [11].

Functional food in the form of synbiotic biscuits can be made by using a combination of sorghum flour which acts as a prebiotic and L. acidophilus bacteria as probiotics. Sorghum flour is one of the prebiotic ingredients because it contains food fibers that cannot be digested and absorbed by the human digestive system but has a very important function for maintenance in nutritional therapy. These components include nondigestible polysaccharides, such as cellulose, hemicellulose, and oligosaccharides [2].

The use of sorghum flour as a raw material for biscuit production has not fulfilled the quality requirement for protein in the biscuit according to SNI (Indonesian National Standard) 1992, that is $9 \%$ so it needs to be added another ingredient that has high protein content. One of them is soybean flour from soybean Anjasmoro varieties which have protein content 39,40\% [17]. Soybean flour is selected because the production of soybean is increasing every year while the utilization still limited. Soybean is generally used as the basic ingredient of making tempeh, tofu, soy milk, and which is being developed is the utilization of soybean flour [21].

The addition of L. acidophilus as probiotic to the synbiotic biscuits cannot be added in pure culture form be coated in the microencapsulation process and dried by freeze drying method to become freeze dried culture in powder form. According to [18], microencapsulated technology developed in probiotic cultures is able to protect probiotic bacterial cells from damage caused by processing, application of dried food products, storage processes and $\mathrm{pH}$ and bile salts produced by the gastrointestinal system.

According to [6], a product can be said a probiotic product if it contains probiotic bacteria 6-8 $\mathrm{Log}_{\mathrm{CFU} \mathrm{m}}{ }^{-1}$ and it's expected to develop into $12 \mathrm{Log} \mathrm{CFU} \mathrm{ml}^{-1}$ in the colon. The number of live probiotics should be able to pass through unfavorable environmental conditions such as exposure to stomach acid and bile salts, so that it still has activity. Based on these standards synbiotic biscuits should also contain at least $7 \mathrm{Log}$ CFU of probiotic bacteria per gram of biscuit.

According to [16], the addition of freeze dried culture less than $6 \%$ does not fulfill the total requirements of probiotic bacteria and the addition of freeze dried culture of $16 \%$ indicates the total LAC (Lactic Acid Bacteria) yield of $9.23 \mathrm{CFU} \operatorname{Log~g}^{-1}$ that has exceeded the standard of probiotics.

Based on the description, it is necessary to do research on the effect of freeze dried $L$. acidophilus culture concentration on the characteristics of synbiotic biscuits made from sorghum flour and soybean flour which is good and fulfill the standard of synbiotic product.

\section{MATERIAL AND METHODS}

Materials used in this study were a local cultivar Bandung sorghum, soybean Anjasmoro varieties, sugar, salt, margarine, eggs, material developers, full cream milk, and pure cultures of L. acidophilus from Food Microbiology Laboratory, MRS agar, glacial acetic acid, $\mathrm{NaCl}$ physiological 0.85\%, aquades, $70 \%$ alcohol, spiritus. The tools used include vacuum oven, grinder, tray, bowl, mixer, analytical balance, rolling pin, biscuit mold, 80 mesh sieve, spoon, beaker glass, spatula, erlenmeyer, petri dish, test tube, reaction tube shelf, bulb pipette, bunsen, mask, rubber gloves, incubator, microscope, colony counter. 
The method used was a randomized block design at the level of trust $\alpha=0.05$, and the treatment in this study was concentration of freeze dried L. acidophilus culture of total flour as much as $8 \%, 10 \%, 12 \%, 14 \%$ and replicated 3 times.

\subsection{Implementation of Research}

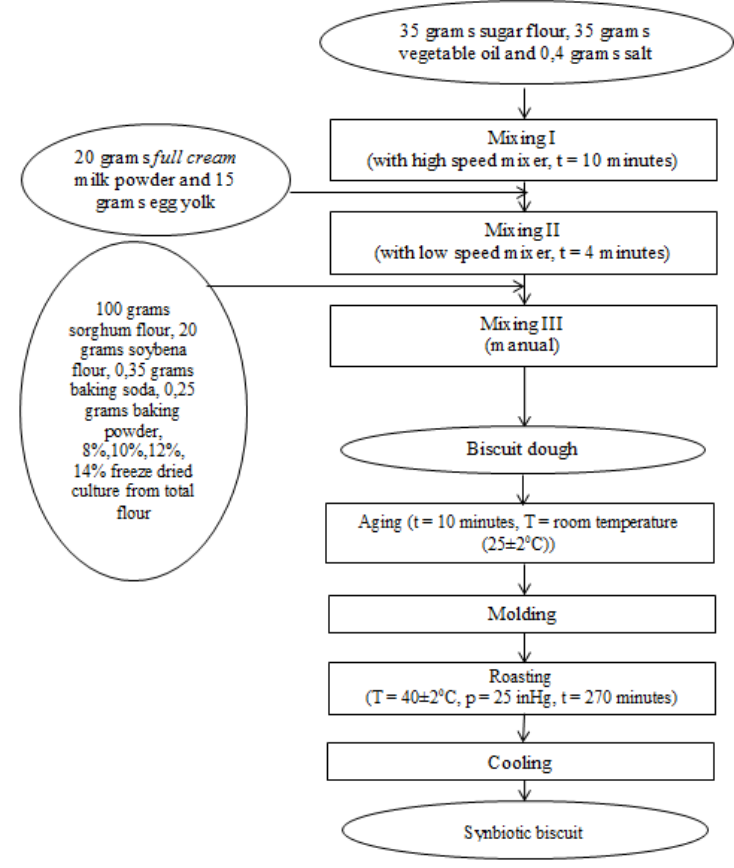

Figure 1. Diagram Manufacturing Process of Synbiotic Biscuits Made from Sorghum Flour and Soybean Flour

\subsection{Analysist Procedure}

\subsubsection{Calculation of Total Bacteria Probiotic on synbiotic biscuits with Total Plate Count method [13].}

$1 \mathrm{ml}$ sample diluted at $9 \mathrm{ml}$ of $0.85 \% \mathrm{NaCl}$ physiological solution, up to $10^{-9}$ aseptically. Each tube in the last three dilutions, pinched each $1 \mathrm{ml}$ into a sterile petri dish. Pour MRS medium and added $0.5 \%$ glacial acetic acid by $12-15 \mathrm{ml}$ into a petri dish, then incubated at $37^{\circ} \mathrm{C}$ for 48 hours. The number of colonies grown on agar was counted by

Colonies per $\mathrm{mL}=$ total colonies per dish $\mathrm{x} \frac{1}{\text { dilution factor }}$

\subsubsection{Analysis of Organoleptic} Characteristics with Hedonic Test on Color, Aroma, Flavor and Texture

Hedonic test was performed on the product by 15 semi trained panelist. The panelist gave their preferences on color, aroma, flavor and texture of the product.

\subsubsection{The Yield Calculation of Synbiotic Biscuit Made from Sorghum Flour and Soybean Flour}

The yield of synbiotic biscuit was calculated as follow:

$$
\text { Yield }=\frac{\text { biscuit } \text { weight }}{\text { dough weight }} \times 100 \%
$$

\section{RESULTS AND DISCUSSION}

\subsection{Total Probiotic Bacteria in Synbiotic Biscuits}

Based on the statistical analysis, the addition of freeze dried culture of $L$. acidophilus gave a significant different effect on total probiotic bacteria. The effect of freeze dried L. acidophilus culture on the total probiotic bacteria can be seen in Table 1 .

Table 1. Effect of Addition Freeze Dried $L$. acidophilus Culture to Total Probiotic Bacteria on Synbiotic Biscuits

\begin{tabular}{|c|c|}
\hline Treatment & Average (Log CFU/g) \\
\hline A (8\%) & $8,65 \mathrm{~d}$ \\
\hline $\mathrm{B}(10 \%)$ & $8,95 \mathrm{c}$ \\
\hline $\mathrm{C}(12 \%)$ & $9,88 \mathrm{~b}$ \\
\hline $\mathrm{D}(14 \%)$ & $10,67 \mathrm{a}$ \\
\hline
\end{tabular}

Different letter means significant different at 95\% level

According to Table 1, the average total probiotic bacteria in treatment $\mathrm{D}$ has significantly higher than those other treatments. The addition of freeze dried $L$. acidophilus culture concentration is proportional to the total number of probiotic bacteria produced. The higher concentration of freeze dried L. acidophilus culture added to the synbiotic biscuit dough, the higher 
number of probiotic bacteria contained in 1 gram of synbiotic biscuit.

The total number of probiotic bacteria contained in the synbiotic biscuits of the study ranged from 8.65 to $10.67 \mathrm{Log} \mathrm{CFU} / \mathrm{g}$. The total number of probiotic bacteria of the study has fulfilled International Standards of FAO/WHO [6], where a product can be said as a probiotic product if it contains probiotic bacteria of at least $7 \mathrm{Log} \mathrm{CFU} / \mathrm{g}$ products and expected to develop into $12 \mathrm{Log} \mathrm{CFU} / \mathrm{g}$ in the colon.

The total probiotic bacteria contained in the synbiotic biscuits is influenced by several factors, that is viability of freeze dried $L$. acidophilus culture, freeze dried L. acidophilus culture concentration added, baking temperature and time, water availability, and nutrition [19].

\subsection{Characteristics of Organoleptic Synbotic Biscuit Color}

The difference in the treatment of freeze dried L. acidophilus concentration on the synbiotic biscuits made from sorghum flour and soybean flour gave no significant effect on the color preferences of the synbiotic biscuits. The effect of the addition of freeze dried L. acidophilus culture to the color of synbiotic biscuits made from sorghum flour and soybean flour can be seen in Table 2 .

Table 2. Effect of Addition Freeze Dried $L$. acidophilus Culture to the Color of Synbiotic Biscuits

\begin{tabular}{|c|c|}
\hline Treatment & Average \\
\hline $\mathrm{A}(8 \%)$ & $3,38 \mathrm{a}$ \\
\hline $\mathrm{B}(10 \%)$ & $3,54 \mathrm{a}$ \\
\hline $\mathrm{C}(12 \%)$ & $3,50 \mathrm{a}$ \\
\hline $\mathrm{D}(14 \%)$ & $3,40 \mathrm{a}$ \\
\hline
\end{tabular}

Different letter means significant different at 95\% level

Based on Table 2. the mean value of the color preferences ranged from 3.38 to 3.54 indicating that the panelists is ordinary to like the color of the synbiotic biscuits. The color of the welted biscuit is golden yellow. The golden yellow color of this synbiotic biscuit is produced from the addition of margarine and egg yolk in the dough. This golden yellow color is also caused by the roasting process.

\subsection{Characteristics of Organoleptic Synbotic Biscuit Aroma}

The treatment of freeze dried $L$. acidophilus culture concentration on the manufacture of biscuit biscuits made from sorghum flour and soybean flour gave a significant different effect on the aroma of synbiotic biscuits. The effect of adding freeze dried L. acidophilus to the aroma of synbiotic biscuits made from sorghum flour and soy flour can be seen in Table 3 .

Table 3. Effect of Addition Freeze Dried $L$. acidophilus Culture to the Aroma of Synbiotic

\begin{tabular}{|c|c|}
\multicolumn{2}{c}{ Biscuits } \\
\hline Treatment & Average \\
\hline A $(8 \%)$ & $3,77 \mathrm{a}$ \\
\hline B $(10 \%)$ & $3,46 \mathrm{~b}$ \\
\hline C $(12 \%)$ & $3,48 \mathrm{~b}$ \\
\hline D $(14 \%)$ & $3,21 \mathrm{c}$ \\
\hline
\end{tabular}

Different letter means significant different at 95\% level

The resulting synbiotic biscuits have a distinctive aroma of baking. The aroma of the synbiotic biscuits is influenced by several factors, such as the aroma of basic ingredients (sorghum flour and soybean flour) and aromas that arise from the heating process like from margarine that can give a distinctive aroma of baking.

\subsection{Characteristics of Organoleptic Synbotic Biscuit Taste}

The treatment of freeze dried $L$. acidophilus culture concentration on the manufacture of biscuits made from sorghum flour and soybean flour gave no significant effect on the taste of the synbiotic biscuits. The effect of freeze dried L. acidophilus culture on the taste of synbiotic biscuits made from sorghum flour and soybean flour can be seen in Table 4.

Table 4. Effect of Addition Freeze Dried $L$. acidophilus Culture to the Taste of Synbiotic Biscuits

\begin{tabular}{|c|c|}
\hline Treatments & Average \\
\hline $\mathrm{A}(8 \%)$ & $3,40 \mathrm{a}$ \\
\hline $\mathrm{B}(10 \%)$ & $3,27 \mathrm{a}$ \\
\hline $\mathrm{C}(12 \%)$ & $3,34 \mathrm{a}$ \\
\hline $\mathrm{D}(14 \%)$ & $3,25 \mathrm{a}$ \\
\hline
\end{tabular}

Different letter means significant different at 95\% level 
According to Table 4, the average value of taste preferences ranged from 3.25 to 3.40 indicating that the panelists preferences are ordinary to the taste of the synbiotic biscuits. The treatment of freeze dried L. acidophilus culture concentration did not affect the taste preferences of the synbiotic biscuits. This is because the freeze dried culture of $L$. acidophilus has no distinctive flavor, so it does not affect the taste of the result of synbiotic biscuits. Synbiotic biscuits made from sorghum flour and soybean flour have a sweet taste and a little savory. The flavor can be caused by several factors, which are the flavors of the ingredients used that is sorghum flour and soybean flour and from the other ingredients such as margarine, starch sugar, salt, egg yolks, full cream milk powder.

In addition, the roasting process causes raw materials such as soybean flour which has a high protein content have Maillard reaction that produces melanoidin compounds which are the main components in making the color and taste (Manley, 2001). This melanoidin compound will produce sensory characteristics that stimulate receptors in taste sensation in the panelist tongue to produce a taste sensation favored by the panelist.

\subsection{Characteristics of Organoleptic Synbotic Biscuit Texture}

The treatment of freeze dried $L$. acidophilus culture concentration on the manufacture of synbiotic biscuits made from sorghum flour and soybean flour did not give a significant effect on the texture preferences of the synbiotic biscuits. The effect of freeze dried L. acidophilus culture on the texture of the synbiotic biscuits made from sorghum flour and soybean flour can be seen in Table 5.

Table 5. Effect of Addition Freeze Dried $L$. acidophilus Culture to the Texture of Synbiotic Biscuits

\begin{tabular}{|c|c|}
\hline Treatments & Average \\
\hline A $(8 \%)$ & $2,59 \mathrm{a}$ \\
\hline $\mathrm{B}(10 \%)$ & $3,04 \mathrm{a}$ \\
\hline $\mathrm{C}(12 \%)$ & $2,88 \mathrm{a}$ \\
\hline $\mathrm{D}(14 \%)$ & $2,67 \mathrm{a}$ \\
\hline
\end{tabular}

Different letter means significant different at 95\% level
According to Table 5, the average value of preference to the texture ranges from 2.59 to 3.04 indicating that the panelists preferences are less likely to ordinary to the texture of the result synbiotic biscuits. This is because the freeze dried L. acidophilus culture texture is a fine grain, so it does not affect the texture of the result synbiotic biscuits.

Synbiotic biscuit texture produced rather hard and not easily broken. Texture is influenced by the ingredients used and the process of kneading and baking. The quality of the texture is influenced by the size of the starch particles as the raw material. Flour with a fine particle size will give a good texture and soft. Sorghum flour has a size of starch granules that are slightly oval and there are some corners (Andrasyifa, 2016).

\subsection{Yield}

Based on the result of statistical analysis, the addition of freeze dried L. acidophilus culture gave a significant different effect on the yield. The effect of freeze dried $L$. acidophilus culture on the yield can be seen in Table 6.

Table 6. Yield Synbiotic Biscuit

\begin{tabular}{|c|c|}
\hline Treatment & Average (\%) \\
\hline $\mathrm{A}(8 \%)$ & $91,86 \mathrm{~b}$ \\
\hline $\mathrm{B}(10 \%)$ & $92,51 \mathrm{a}$ \\
\hline $\mathrm{C}(12 \%)$ & $92,31 \mathrm{a}$ \\
\hline $\mathrm{D}(14 \%)$ & $92,14 \mathrm{a}$ \\
\hline
\end{tabular}

Different letter means significant different at 95\% level

Based on Table 6, treatment A gave the lowest yield. The other treatments gave the same yield. The result complied with the statement of Raharjo [20], that is when the material is dried at the same temperature, $\mathrm{RH}$ and time then the amount of water in the evaporating material during the heating process will be the same.

The synbiotic biscuit products made from sorghum flour and soybean flour can be seen in Figure 2. 


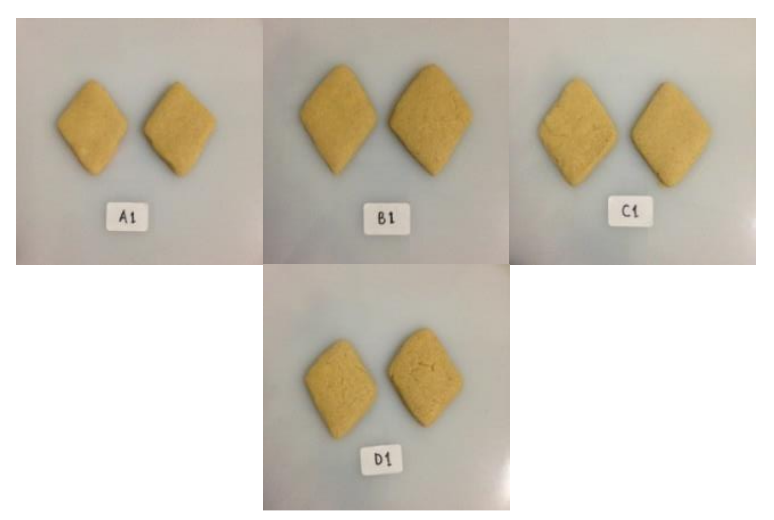

Figure 2. Synbiotic Biscuits Made from Sorghum Flour and Soybean Flour; (a) Treatment A (freeze dried L. acidophilus concentration 8\%); (b) Treatment B (freeze dried L. acidophilus concentration 10\%); (c)

Treatment C (freeze dried L. acidophilus concentration 12\%); (d) Treatment D (freeze dried L. acidophilus concentration 14\%)

\section{CONCLUSSION}

Based on the results of research that has been done, it can be concluded that the addition of freeze dried culture of $L$. acidophilus on synbiotic biscuits made from sorghum flour and soybean flour have a significant effect on total L. acidophilus probiotic bacteria, aroma and yield, but on the color, taste and texture, it gave no significant effect. Synbiotic biscuits with the addition of freeze dried L. acidophilus concentration of $14 \%$ $(\mathrm{w} / \mathrm{w})$ were selected as the best characteristic synbiotic biscuits with total bacterial content of probiotics 10,67 Log CFU g-1, were perceived a bit like to like by the panelist and the obtained yield was $92,14 \%$.

\section{ACKNOWLEDGEMENT}

The authors thank to Universitas Padjadjaran for providing financial support through Unpad Lecturers Competence Grant, to parents who give full support especially morally and to all friends who have taken time helping this research.

\section{REFERENCES}

[1] Andrasyifa, D. 2016. Karakteristik Fisikokimia dan Fungsional Tepung Sorgum (Sorghum bicolor $L$. Moench) Modifikasi Cross-link Menggunakan Sodium Tripoliposfat
(STPP). Skripsi, Fakultas Teknologi Industri Pertanian. Universitas Padjadjaran, Jatinangor.

[2] Astawan, M. dan T. Wresdiyati. 2004. Diet Sehat dengan Makanan Berserat. Tiga Serangkai Pustaka Mandiri, Solo.

[3] Badan Standarisasi Nasional .1992. Standardisasi Nasional Indonesia (SNI) Nomor 01-2973-1992, Mutu dan Cara Uji Biskuit. Departemen Perindustrian Indonesia, Jakarta.

[4] Balitkabi. 2005. Deskripsi Varietas Unggul Kacang-kacangan dan Umbiumbian. Malang.

[5] BPOM, Badan Pengawas Obat dan Makanan Republik Indonesia. 2005. Pengaturan Kepala Badan Pengawasan Obat dan Makanan Republik Indonesia Tentang Ketentuan Pokok Pengawasan Pangan Fungsional. BPOMRI, Jakarta.

[6] FAO/WHO.2002. Guidelines for the Evaluation of Probiotics in Food. Report of Joint FAO/WHO Working Group on Drafting Guidelines for the Evaluation of Probiotics in Food. London Ontario, Canada.

[7] Ide, P. 2008. Health Secret Of Kefir. PT Elex Media Komputindo, Jakarta.

[8] Manley, D. 2001. Biscuits, Cookie, and Cracker Recipes for The Food Industry. Woodhead Publishing Limited, Cambridge.

[9] Muchtadi, D. 2012. Karbohidrat Pangan dan Kesehatan. Alfabeta, Bandung.

[10] Nurhidayati. 2006. Analisis Faktorfaktor yang Mempengaruhi Rendemen. Fakultas Ekonomi Universitas Islam Indonesia, Jakarta.

[11] Persatuan Ahli Gizi Indonesia. 2009. Tabel Komposisi Pangan Indonesia. PT Elex Media Komputindo, Jakarta.

[12] Roberfroid, M. 2005. Inulin-type fructans: Functional Food Ingredients. CRC Press, Florida. 
[13] Rosiana, A. D., N. Emma N. S. Dan Isnaeni. 2008. Pengaruh Asam asam Organik Terhadap Pertumbuhan Lactobacillus acidophilus, Lactobacillus bulgarixus dan Lactobacillus casei (Bakteri Asam Laktat). Departemen Kimia Farmasi, Fakultas Farmasi, Universitas Airlangga, Surabaya.

[14] Sirappa, M. P. 2003. Prospek Pengembangan Sorgum di Indonesia Sebagai Komoditas Alternatif untuk Pangan, Pakan, dan Industri. Jurnal Litbang Pertanian, 22(4), 2003.

[15] Soekarto, S. T. 1985 Penilaian Organoleptik untuk Industri Pangan dan Hasil Pertanian. Liberty, Yogyakarta.

[16] Widarta, F. 2012. Kajian Penambahan Kultur Freeze Dried Terhadap Karakteritsik Biskuit Sinbiotik Berbahan Baku Tepung Komposit. Skripsi. Fakultas Teknologi Industri Pertanian, Universitas Padjadjaran, Jatinangor.

[17] Widodo, S. 2001. Pengaruh Suhu dan Lama Perkecambahan Biji Kedelai (Glycinemax) terhadap Mutu Kimia dan Nutrisi Tepung yang Dihasilkan. Skripsi. Fakultas Teknologi Pertanian Universitas Brawijaya, Malang.

[18] Zuidam, N. J. dan E. Shimoni. 2010.

Overview of Microencapsulates for Use in Food Products or Processes and Methods to Make Them. Springer. London.

[19] Fardiaz, S. 1992. Analisis Mikrobiologi Pangan. Raja Grapindo Persada, Jakarta.

[20] Raharjo, S.A. 2010. Pengaruh Imbangan Tepung Beras Sorgum dari Berbagai Lama Penyosohan dengan Tepung Tapioka Terhadap Rendemen dan Karakteristik Kerupuk. Skripsi. Fakultas Teknologi Industri Pertanian.
Universitas Padjadjaran, Jatinangor.

[21] Santoso. 2005. Teknologi Pengolahan Kedelai (Teori dan Praktik). Universitas Widyagama. Malang 